University of Nebraska - Lincoln

DigitalCommons@University of Nebraska - Lincoln

\title{
When the Romance is Over: Follower Perspectives of Aversive Leadership
}

\author{
Michelle C. Bligh \\ Claremont Graduate University, michelle.bligh@cgu.edu \\ Jeffrey C. Kohles \\ California State University San Marcos \\ Craig L. Pearce \\ University of Nebraska - Lincoln, cpearce2@unl.edu \\ Joseph E. (Gene) Justin \\ University of Redlands \\ John F. Stovall \\ California State University Bakersfield
}

Follow this and additional works at: https://digitalcommons.unl.edu/leadershipfacpub

Part of the Management Sciences and Quantitative Methods Commons

Bligh, Michelle C.; Kohles, Jeffrey C.; Pearce, Craig L.; Justin, Joseph E. (Gene); and Stovall, John F., "When the Romance is Over: Follower Perspectives of Aversive Leadership" (2007). Leadership Institute Faculty Publications. 21.

https://digitalcommons.unl.edu/leadershipfacpub/21

This Article is brought to you for free and open access by the Leadership Institute at DigitalCommons@University of Nebraska - Lincoln. It has been accepted for inclusion in Leadership Institute Faculty Publications by an authorized administrator of DigitalCommons@University of Nebraska - Lincoln. 


\title{
When the Romance is Over: Follower Perspectives of Aversive Leadership
}

\author{
Michelle C. Bligh \\ Claremont Graduate University \\ Jeffrey C. Kohles \\ California State University San Marcos
}

Craig L. Pearce

Claremont Graduate University

Joseph E. (Gene) Justin

University of Redlands

John F. Stovall

California State University Bakersfield

\begin{abstract}
Corresponding author - Michelle C. Bligh, School of Behavioral and Organizational Sciences, Claremont Graduate University, 123 East Eighth Street, Claremont, CA 91711;

E-mail michelle.bligh@cgu.edu
\end{abstract}

\begin{abstract}
While leadership is indisputably one of the most pervasive topics in our society, the vast majority of existing research has focused on leadership as a positive force. Taking a follower-centric approach to the study of leadership, we integrate research on the Romance of Leadership and the dark side of leadership by examining followers' perceptions of aversive leadership in the context of public high schools. Although Meindl, Ehrlich, and Dukerich (1985) demonstrated that the Romance of Leadership also includes the overattribution of negative outcomes to leaders, subsequent research has failed to explore the implications of this potentially darker side of romanticizing leaders. Specifically, we examine perceptions of principals' aversive leadership and traditional affective, behavioral, and performance outcomes of followers in a sample of 342 dyads. Followers assessed their principals' leadership behaviors and self-rated their levels of job satisfaction, self-efficacy, and resistance, while principals assessed their followers' citizenship behaviors, complaining behaviors, and job performance. Results show that perceptions of aversive leadership
\end{abstract}


are positively related to follower resistance and negatively related to followers' job satisfaction. In addition, a usefulness analysis revealed that follower-rated variables were significantly related to perceptions of aversive leadership above and beyond leader-rated variables, suggesting that the relationship between negative outcomes and aversive leadership may be more constructed than real. In sum, the tendency to romanticize leadership may also lead to a proclivity to readily misattribute or overattribute blame to leadership as a convenient scapegoat for negative outcomes.

Alors que le leadership est incontestablement l'un des thèmes les plus envahissants de notre société, la grande majorité des recherches existantes a porté sur le leadership en tant que force positive. En adoptant une approche centrée sur le suiveur dans l'étude du leadership, nous examinant la perception qu'ont les collaborateurs du leadership insupportable dans le contexte des lycées publics. Quoique Meindl, Ehrlich, et Dukerich (1985) aient montré que la Romance du Leadership inclut aussi la surattribution de résultats négatifs aux leaders, les recherches ultérieures ont méconnu les implications de cet aspect potentiellement plus sombre des leaders idylliques. Nous analysons en particulier sur un échantillon de 342 dyades la perception du leadership répulsif du proviseur et les résultats habituels des collaborateurs en rapport avec l'affectivité, le comportement et les performances. Les collaborateurs ont noté les comportements de leadership de leur proviseur et autoévalué leur niveau de satisfaction au travail, d'efficience et de résistance, alors que les proviseurs appréciaient les conduites de citoyenneté et de revendication, ainsi que la performance professionnelle. Les résultats montrent que la perception du leadership répulsif est Positivement reliée à la résistance du suiveur et négativement à sa satisfaction professionnelle. En outre, une analyse des plus fructueuses a révélé que les variables évaluées par les collaborateurs étaient significativement en relation avec la perception du leadership répulsif, bien plus qu'avec les variables évaluées par les leaders, ce qui indique que la relation entre les résultats médiocres et le leadership négatif serait plus construite que réelle. Au total, le penchant à l'idéalisation du leadership peut aussi bien conduire à une propension à trop facilement condamner à tort et à travers le leadership qu'à la désignation d'un bouc émissaire tout trouvé pour expliquer de mauvais résultats.

The concept of leadership is a permanently entrenched part of the socially constructed reality that we bring to bear in our analysis of organizations. And there is every sign that the obsessions and celebrations of it will persist. (Meindl, Ehrlich, \& Dukerich, 1985, p. 78)

Leadership, in effect, is too important to be left to leaders. (Grint, 2000, p. 4)

\section{Introduction}

The purpose of this paper is to integrate research on the "Romance of Leadership" and the "dark side" of leadership by examining followers' perceptions of aversive leadership. In particular, we hope to shed some light on the dark side of leadership, a side that has received comparatively little theoretical or 
empirical attention (Conger, 1990; Hogan, Raskin, \& Fazzini, 1990; Pearce, Sims, Cox, Ball, Schnell, Smith, \& Trevino, 2003). Namely, we examine the potential destructive halo effect of follower perceptions of aversive leadership, or leadership behaviors that emphasize the use of threats, intimidation, and punishment (Pearce et al., 2003; Pearce \& Sims, 2002). In contrast to the familiar halo effect that has been well documented in leadership research, we explore what may perhaps be more accurately referred to as a "horns" effect: the negative relationship between follower perceptions of aversive leadership and traditional affective, cognitive, behavioral, and performance outcomes of followers.

While leadership is indisputably one of the most discussed, studied, and written about topics in our society (see Bligh \& Meindl, 2004), the vast majority of existing research and theoretical work has focused on leadership as a positive force on followers and society, rather than the potential dark side of leadership (see Goldman, 2006, for a recent exception). As Meindl et al. (1985, p. 79) point out, "the romanticization of leadership is hinted at in the observations made by a number of social and organizational analysts who have noted the esteem, prestige, charisma, and heroism attached to various conceptions and forms of leadership". Although Meindl et al. (1985) demonstrated that the Romance of Leadership also includes attribution of negative outcomes to leaders, subsequent research has failed to adequately explore the implications of this potentially darker side of romanticizing leaders. As a recent example, a subject search of "leadership" on Amazon.com in 2005 yielded 8,887 books on the subject, yet just 10 per cent of these books (929) address the issue of "destructive" or "negative" forms of leadership (see Kellerman, 2004; Lipmann-Blumen, 2006; and Schilling, this volume, for recent examples).

Accordingly, the study of leadership as a potentially detrimental or destructive force in organizations is an area deserving increased attention. Although Meindl et al. (1985) strongly advocated that we critically question the use of leadership as a causal attribution for a variety of complex organizational outcomes, we suggest that leadership scholarship itself has been guilty of focusing more attention on this social psychological phenomenon as a positive force. As a result, Meindl's legacy has primarily been enacted as a critique of our fascination with leadership, and our emphasis on heroism, charisma, and the glorification of leadership in the face of any real evidence that a given leader has been efficacious. What has been for the most part neglected in this legacy is how the "romance of leadership" also leads us to readily blame leaders for negative outcomes, even in the absence of any real evidence that they are blameworthy.

Previous scholarship in the realm of leadership provides an important window into our beliefs as a society about the topic: what constitutes leadership, why it is important, what makes it successful, and what attributions we make about the effects of leadership. From a social constructionist approach (Berger \& Luckmann, 1966; Gergen, 1999; Meindl, 1995), our understanding and implicit 
theories about leadership are influenced by how it is collectively defined and discussed, and the types of leadership that are idealized and demonized (Salancik \& Pfeffer, 1978). Leadership concepts represent particularly salient socially constructed realities that evolve over time (see Calder, 1977; Chen \& Meindl, 1991; Salancik \& Pfeffer, 1978; Meindl, 1990; Meindl et al., 1985; van Knippenberg, van Knippenberg, \& Giessner, 2007). A recent analysis of popular leadership books, for example, reveals that leaders are seen as effecting change, possessing great experience and knowledge, and providing their followers with opportunities to reach their unique potential. These conceptualizations all fit our cultural stereotypes of a "great leader" (Bligh \& Meindl, 2004). However, although much has been written about positive leadership, less attention has been paid to the more destructive types of leadership and the methods available to reduce its impact on organizations.

This largely positive approach to leadership may be explained in part by the Romance of Leadership perspective as originally developed by Meindl et al. (1985). Their examination of the leadership literature and empirical work revealed that leaders and leadership issues often become the favored explanations for both positive and negative outcomes in and around organizations. In addition, subsequent research has demonstrated that people value performance results more highly when those results are attributed to leadership, and that a halo effect exists for leadership attributes: if an individual is perceived to be an effective leader, his or her personal shortcomings and poor organizational performance may be overlooked (Meindl \& Ehrlich, 1987).

This so-called "Romance of Leadership" is strongly reflected in the constructions of leadership that are widely produced for our consumption in the popular press (Bligh \& Meindl, 2004; Klapp, 1964; Goode, 1978). Whether in the form of portraits or images of great leadership figures (e.g. Boorstin, 1961; Locke, 2000), or portrayals of the never-before-revealed secrets of leadership effectiveness, these images reflect our appetite as a society for leadership products and behaviors that promise to enrich and improve our lives. These leadership images appeal not only to our cultural fascination with the power of leadership, but also serve to fixate us on the personas and characteristics of leaders themselves (Meindl, 1990). However, this one-sided emphasis on the positive forms of leadership can be dangerous, for it suggests that leaders are inherently positive forces for individuals, organizations, and humanity as a whole, and may underline a Romance of Leadership at the societal level as well. Although Meindl et al. (1985) demonstrated that the Romance of Leadership also includes attribution of negative outcomes to leaders, subsequent research has failed to explore the implications of this potentially darker side of romanticizing leaders. Further research is clearly warranted on the various forms that harmful leadership may take, and what drives perceptions of harmful or aversive leadership. 
In the current study, our goal is twofold: (1) to test a traditional model of consequences or outcomes of aversive leadership that involves intimidation and reprimands; and (2) to test aversive leadership as a social construction of followers in the tradition of Romance of Leadership. Specifically, we explore the idea that followers may tend to readily blame leaders for negative outcomes, even in the absence of any real evidence that the leader is to blame. Accordingly, we first review previous research on a wide variety of destructive and aversive leadership personality types and behaviors. Next, we articulate the potential relationship between aversive leadership and traditional follower affective, cognitive, behavioral, and performance outcomes. Subsequently, we empirically test our hypothesized relationships, examining what drives perceptions of aversive leadership in followers. Finally, we integrate our results with the extant literature and offer some conclusions and implications of the positive "Romance of Leadership" bias in leadership research.

\section{Integrating the Romance of Leadership and the Dark Side of Leadership}

The "Romance of Leadership" is the tendency to attribute responsibility for either positive or negative outcomes to leaders (Meindl, 1995; Meindl et al., 1985). According to Meindl et al. (1985, p. 80), "the romanticized conception of leadership results from a biased preference to understand important but causally indeterminate and ambiguous organizational events and occurrences in terms of leadership". While several studies have examined how followers react to leaders when they tend to romanticize leadership (e.g. Awamleh \& Gardner, 1999; Bligh, Kohles, \& Pillai, 2005; Gardner, 2003), the vast majority of this research has focused on the positive implications (i.e. followers put more effort into their work in order to fulfill their own expectations about what the leader is capable of achieving). However, what happens when followers attribute negative outcomes to leaders? In the latter situation, we might expect a wide array of follower attitudes, behaviors, and performance outcomes to be systematically and negatively affected. In other words, while most previous research has concentrated primarily on (over)attributions of success (with the exception of Meindl et al., 1985), in the current study we examine the potential for (over)attribution of failure.

As Burns (2005, p. 12) notes, "leadership, in common parlance, is a 'good'”. However, Meindl and his colleagues were influential in encouraging us as consumers of leadership to continually question the social construction of leadership itself, and the prevailing emphasis on "the good" in leadership (see also Weick, 2007). In the current study, we follow this tradition and Meindl et al.'s 
(1985, p. 100) assertion that "the continuing infatuation with leadership, for whatever truths it yields about the qualities and behavior of our leaders, can also be used to learn something about the motivations of followers". In other words, this perspective encourages us to approach ratings and perceptions of leaders' behaviors not as "objective" measures of leadership, but as important insights into how followers conceptualize those behaviors and their potential impacts (see also Schyns, Felfe, \& Blank, this volume). As Meindl (1995, pp. 330-331) points out, this approach "assumes that followers react to, and are more influenced by, their constructions of the leader's personality than they are by the 'true' personality of the leader . . . it is the personalities of leaders as imagined or constructed by followers that become the object of study, not 'actual' or 'clinical' personalities per se." Accordingly, in the current study we examine the potential implications and perceived outcomes when followers' constructions of their leaders are negative or aversive.

Researchers have long recognized that leaders sometimes make decisions that harm individual organizational members and long-term organizational performance (Mumford, Gessner, Connelly, O'Connor, \& Clifton, 1993). Unfortunately, leaders are not always interested in effecting change for the benefit of others or for the organization as a whole ( $\mathrm{O}^{\prime}$ Connor, Mumford, Clifton, Gessner, \& Connelly, 1995), and a variety of antecedents have been explored in order to explain this type of "deviant" leadership behavior. We review several previous streams of literature that examine the darker side of leadership to move toward the integration of a Romance of Leadership perspective with these previous research streams. In particular, a number of personality characteristics have been identified in the literature as related to aversive forms of leadership, including a personalized power orientation, narcissism, fear, antisocial personality disorder, and inadequate self-esteem (Goldman, 2006; O'Connor et al., 1995). Mumford et al. (1993) found that leaders who engaged in destructive acts tended to make decisions that harmed the organization when their self-efficacy was low. Other research has related certain destructive behaviors to lack of empathy and the belief that others can legitimately be manipulated (Eisenberg \& Miller, 1987; Hunter, Gerbing, \& Boster, 1982).

Still other researchers have explored "generalized workplace aggression", which in some cases may be utilized by leaders to advance their organizational or personal goals. O'Connor et al. (1995) suggest that a leader with what they call "object beliefs", or leaders who focus primarily on workplace outcomes and how to achieve those outcomes, will be more likely to see actions that result in harm to others as a legitimate path to goal achievement and will discount the impact of these behaviors on others when choosing a course of action (see also Locke, 1991). Neuman and Baron (1998, p. 395) define workplace aggression as "efforts by individuals to harm others with whom they work". In Glomb and Liao's (2003) definition of interpersonal workplace ag- 
gression, however, they also include less extreme aggressive behaviors (such as yelling at another person, talking behind another person's back, or withholding needed resources from another) in addition to the more extreme behaviors usually associated with workplace violence (such as physical assault and threats of violence). Other work in this area addresses concepts such as organizational retaliatory behaviors (Skarlicki \& Folger, 1997), revenge responses (Bies, Tripp, \& Kramer, 1997), workplace deviance (Robinson \& Bennett, 1995), incivility (Andersson \& Pearson, 1999), and emotional abuse at work (Keashly \& Jagatic, 2003).

Overall, a number of labels have been developed to describe an array of destructive leadership behaviors (see Harlos \& Pinder, 1999, pp. 108-109, for a thorough discussion). Ashforth (1994), for example, defines a "petty tyrant" as an individual who lords his or her power over others. Based on previous empirical work, Ashforth (1994) suggests that tyrannical behaviors take a variety of negative forms, including arbitrariness, self-aggrandizement, lack of consideration, forced conflict resolution, discouragement of initiative, non-contingent punishment, and the belittlement of others. Tepper $(2000,2001)$ defines "abusive leadership" as the extent to which supervisors engage in the sustained display of hostile verbal and nonverbal behaviors, excluding physical contact. In contrast to petty tyranny, abusive leadership encompasses behaviors that reflect indifference (e.g. rudeness), in addition to "willful hostility" (e.g. publicly belittling subordinates in order to hurt their feelings). Tepper's findings suggest that subordinates whose supervisors are more abusive have higher turnover, increased work-family conflict, higher levels of psychological distress, and less job, life, and organizational satisfaction. Moreover, the effects on job satisfaction, life satisfaction, family-to-work conflict, depression, and emotional exhaustion were more pronounced for subordinates who had less job mobility. Thus, when employees did not perceive a "way out", abusive leadership had broad effects on subordinates' attitudes and perceived levels of psychological distress.

Although Meindl et al. (1985) noted the "esteem, prestige, charisma, and heroism" attached to various conceptions and forms of leadership, some scholars have also focused specifically on the potentially negative aspects of charismatic leadership (Bass, 1990; Bass \& Steidlmeier, 1999; Conger, 1989; Conger \& Kanungo, 1998; Hogan et al., 1990; House \& Howell, 1992; Howell, 1988; Kets de Vries \& Miller, 1985; Mumford et al., 1993; O'Connor et al., 1995; Sandowsky, 1995; Yukl, 1999). This research, reviewed by Yukl (2002), suggests that charismatic leaders tend to make riskier decisions that can lead to failure, and they also tend to develop determined enemies who can use these failures as opportunities to undermine the leader's authority and effectiveness. Based on McClelland's (1975) work on motivation, House and Howell (1992) suggest that personalized charismatic leadership includes potentially destructive behaviors such as being exploitative, non-egalitarian, and self-aggrandizing, and there is some ev- 
idence that personalized charismatic leaders may be more likely to employ subtle forms of workplace aggression (see Locke, 1991; O'Connor et al., 1995).

Taken together, the above review suggests that there is a significant body of work that examines more extreme forms of tyranny, workplace deviance, aggression, exploitation, and outright incivility in which both charismatic and non-charismatic leaders may engage (Ashforth, 1994; Baron, 2004; Griffin \& O'Leary-Kelly, 2004; Hogan \& Hogan, 2001; Pearson \& Porath, 2004; see also Harlos \& Pinder, 1999). However, Andersson and Pearson (1999) point out that while research has been conducted into more severe forms of workplace deviance, little research has been conducted on lesser forms of mistreatment that followers often attribute to leaders, such as rude comments, thoughtless acts, or negative gestures (Keashly \& Jagatic, 2003; Neuman \& Baron, 1997). Research by Baron and Neuman (1996) suggests that the majority of workplace deviance is manifested in generally less severe forms: verbal rather than physical, passive rather than active, indirect rather than direct, and subtle rather than overt. These more subtle and indirect manifestations of negative leadership behaviors may importantly influence follower constructions of the leader's efficacy and subsequently have a detrimental relationship with follower attitudes and behaviors in the workplace.

The necessity of studying these less severe forms of aversive leadership is underscored by workplace studies and surveys around the globe suggesting that many of these leadership behaviors are surprisingly prevalent in the workplace. For example, a 1994 survey of university employees in Finland found that approximately one-third of respondents had observed others being exposed to verbally harassing behavior at work (Bjorkqvist, Osterman, \& Hjelt-Back, 1994). Similarly, a survey of front-line American employees revealed that more than half of the 327 respondents reported acts of mistreatment at work over three years (Ehrlich \& Larcom, 1994). In yet another example, Graydon, Kasta, and Khan's (1994) survey of 603 Canadian nurses found that one-third had experienced verbal harassment during the previous five days of work (see also Duncan, Estabrooks, \& Reimer, 2000), and Sofield and Salmond's (2003) study of 461 nurses revealed that 91 per cent had experienced verbal abuse in the past month. Together, these survey findings clearly suggest that milder forms of mistreatment in the workplace, such as rude comments, reprimands, and indirect forms of intimidation, are worthy of scholarly attention (Andersson \& Pearson, 1999; Pearson, Andersson, \& Porath, 2000; Pearson \& Porath, 2004).

In addition, the impact of these behaviors by individuals in positions of authority likely increases their significance (Mumford et al., 1993). In the current study, we examine followers' perceptions of aversive leadership, a set of milder yet potentially destructive leadership behaviors that emphasize the use of intimidation and punishment or reprimands (Pearce et al., 2003; Pearce \& Sims, 2002), and obtain both follower and leader perspectives on the impact of such 
mistreatment on a variety of traditional outcomes in the workplace. This approach allows us to examine whether the detrimental outcomes of perceptions of aversive leadership are apparent to both leaders and followers, or if they are more socially constructed and "in the eye of the beholder" (or in this case, the follower), as the Romance of Leadership theory might suggest.

\section{Perceptions of Aversive Leadership: The "Horns" Effect}

Previous research suggests that destructive forms of leadership have a negative relationship with traditionally desirable follower and organizational outcomes (e.g. Ashforth, 1994; Pearce \& Giacalone, 2003; Tepper, Duffy, \& Shaw, 2001a; Tepper, Lockhart, \& Hoobler, 2001b). In the following section, we explore the relationship between perceptions of a leader's aversive leadership behaviors and a range of traditional follower outcomes that might be negatively impacted by a potential "horns" effect, or reverse halo effect (see Bowman, 1999; Jansen \& Kristof-Brown, 2006), when leaders engage in intimidation or reprimanding behaviors. The term "halo effect" was first coined by Thorndike (1920) to refer to an overall positive evaluation of an employee based on a single positive characteristic or action (see also Lance, LaPointe, \& Fisicaro, 1994; Nisbett \& Wilson, 1977; Viswesvaran, Schmidt, \& Ones, 2005). There is also some evidence for a reverse halo effect, sometimes referred to as the "rusty halo" or "horns" effect (see Baron, 1986), which has been applied to situations in which an overall negative appraisal is made based on one salient failure or negative characteristic. In the current study, we expand the metaphor of the horns effect to the leader-follower relationship in order to examine what drives perceptions of aversive leadership. From a leader-centered, traditional approach, aversive leadership is likely negatively associated with a variety of traditional outcomes in followers, including lowered performance, job satisfaction, and OCBs. From a more follower-centered, social constructionist/Romance of Leadership perspective, however, we suggest that diminished job satisfaction (Tepper, 2000), diminished self-efficacy (see Baron, 1988; Bandura, 1986; Tepper, 2000), and increased resistance (Baron, 1988; Yukl, 2002) may also lead followers to construct negative images of their leader, resulting in increased perceptions of aversive leadership.

\section{Traditional Affective Outcomes}

Abusive supervision has been associated with a variety of negative affective outcomes, including lower job and life satisfaction, lower normative and affective commitment, increased work-family conflict, and increased psychological distress (Tepper, 2000). While abusive leadership is obviously a more extreme form of antisocial behavior, aversive leadership (Pearce et al., 2003; 
Pearce \& Sims, 2002) may also be associated with lower levels of generalized job satisfaction. In 1993-94, the US Department of Education surveyed approximately 36,000 public school teachers in order to explore the factors that influence teacher satisfaction. The findings of this large-scale study suggest that pay, demographic, and background characteristics are not important predictors of teacher job satisfaction; rather, the study found that "involving teachers in school-wide policy decisions and giving them some degree of control in their classrooms are associated with high levels of satisfaction" (Perie, Baker, \& Whitener, 1997, p. 52). Greater involvement and control are related to less job-related stress as well (see also Schwarzer, 2004). These results suggest that teachers who perceive higher levels of aversive leadership from their principals are likely to be less satisfied than those who perceive that their principals use less aversive, and perhaps more participative, leadership styles.

The Perie et al. (1997) large-scale study also suggests that aversive leadership may be related to self-efficacy as well. Self-efficacy is defined as a personal belief concerning "one's capabilities to organize and execute courses of action required to produce given attainments" (Bandura, 1997, p. 3). Contrary to more global perceptions of the self (i.e. self-esteem and self-concept), self-efficacy is task-specific: Individuals may have high self-efficacy for some tasks and low self-efficacy for others. As a result, "self-efficacy is defined and measured in the context of relatively specific behaviors in specific situations or contexts" (Maddux, 1995, p. 8).

Disruptions of positive cognitive processes are predictors of lower levels of self-efficacy (Bandura, 1986). The psychological distress associated with perceptions that one's leader is intimidating and reprimanding may very well impair a follower's belief in his or her ability to perform and achieve desired results and outcomes. Accordingly, we posit that aversive leadership will negatively affect commitment, confidence, and goal setting, ultimately resulting in lower follower job satisfaction and self-efficacy.

H1: Perceptions of aversive leadership will be significantly related to lower follower job satisfaction.

H2: Perceptions of aversive leadership will be significantly related to lower follower self-efficacy.

\section{Traditional Behavioral Outcomes}

Offensive or abusive leadership behaviors have been posited to be a catalyst or justification for employees to engage in a variety of negative behaviors, including corrupt activities (e.g. Dubois, 1979; Giacolone \& Rosenfeld, 1987; Tepper, 2000) and anti-citizenship behaviors (Ball, Sims, \& Trevino, 1994). Specif- 
ically, Ball et al. (1994) found harshness of discipline to be positively related to anti-citizenship behaviors, and Baron's (1988) findings suggest that destructive criticism often leads to increased tension, anger, resistance, avoidance, and lower performance goals. In addition, the perception that the leader is being exploitative or provoking has been linked to higher levels of follower aggressiveness (Hollinger \& Clark, 1983; Mantell, 1994; Torestad, 1990). Ashforth's (1994) work further suggests that petty tyranny leads to reduced productivity and increased levels of complaints, defiance, and withdrawal. In addition, other findings demonstrate that petty tyranny leads to increased organizational dysfunction as well (Ashforth, 1997). The literature on anti-citizenship behavior suggests that employees may use offensive or aversive leader behaviors to justify their own antisocial behavioral manifestations (Dubois, 1979; Giacalone \& Rosenfeld, 1987; Tepper \& Taylor, 2003; Tepper, Hoobler, Duffy, \& Ensley, 2004; Tepper et al., 2001a; Zellars, Tepper, \& Duffy, 2002).

If followers are treated as objects to be manipulated for desired outcomes, as suggested by O'Connor et al. (1995) and Locke (1991), it seems likely that a pattern of treating individuals as objects would diminish voluntary citizenship behaviors. Indeed, Ball et al. (1994) found harshness of discipline to be positively related to certain anti-citizenship behaviors. Each of these findings suggests the possibility that these psychological manifestations could result in expressive behavior, verbal or non-verbal, intended to call attention to the plight of the follower. Thus, we propose that the negative feelings associated with aversive leadership - distress, tension, and anger-will find expression in lowered OCBs, increased complaining behavior, and increased resistance to the methods and objectives of an aversive leader. In addition, following Ashforth's (1994) findings that the behaviors involved in petty tyranny were associated with reduced productivity, and Baron's (1988) results that destructive criticism were associated with lower performance goals, we offer the following hypotheses:

H3: Perceptions of aversive leadership will be significantly related to increased follower resistance.

H4: Perceptions of aversive leadership will be significantly related to higher complaining behaviors.

H5: Perceptions of aversive leadership will be significantly related to lower follower OCBs.

H6: Perceptions of aversive leadership will be significantly related to lower follower performance. 


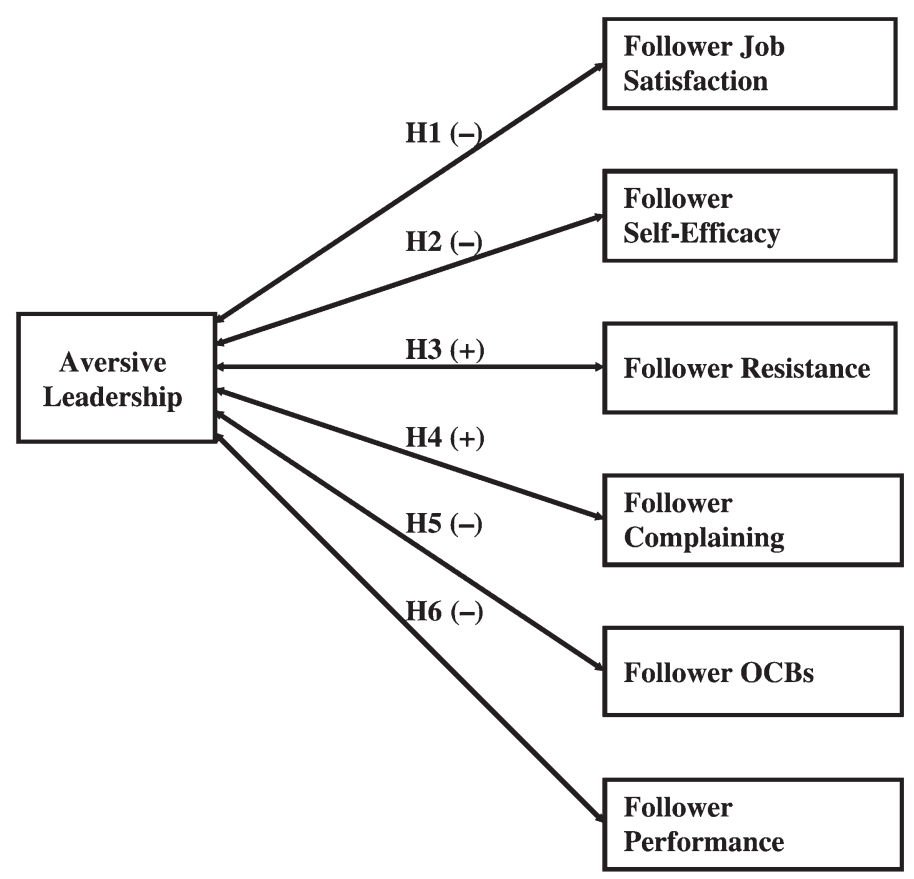

Figure 1. Traditional leader-centered approach: Hypotheses 1-6.

Figure 1 summarizes the six hypotheses, which state that perceptions of aversive leadership will be significantly related to traditional follower outcomes, including job satisfaction, self-efficacy, resistance, complaining, OCBs, and performance.

\section{Evidence that the Romance May Be Over: The "Horns" Effect}

The previous hypotheses outline six traditional outcome variables argued to be negatively related to aversive leadership. Following Meindl's work on the Romance of Leadership, we also sought to explore whether or not aversive leadership (as rated by followers) would be significantly related to both leaderrated and follower-rated outcomes. In other words, just because followers perceive that their leaders are aversive may or may not mean that their behavioral outcomes such as performance, OCBs, and complaining behaviors - as rated by someone else, perhaps a more objective outsider (see Donaldson \& GrantVallone, 2002) - will be related to those perceptions. In fact, it may be just as likely that followers are making a cognitive link between their own negative attitudes and behaviors and something that the leader is doing. In this situation, the leader may or may not be acting in an aversive manner; what may be more 
critical in understanding follower outcomes is whether or not the followers perceive that their self-reported (and experienced) negative outcomes are related to the leader or to what the leader is doing. If both leader and follower outcomes are significantly and negatively related to perceptions of aversive leadership, it is most likely due to either the leader's actual behavior or as a result of the low exchange relationship that the dyad has developed over time: i.e. bad (aversive) leadership leads to negative outcomes that both leaders and followers recognize. From a more constructionist point of view, however, if follower-rated outcomes are more strongly associated with perceptions of aversive leadership than are leader-rated outcomes, then those outcomes may be more likely due to an attributed "horns" effect: i.e. "I have low job satisfaction, self-efficacy, and often resist my leader because I have a bad (aversive) leader."

H7: Follower-rated outcomes will be more useful in explaining perceptions of aversive leadership than leader-rated outcomes.

\section{Method}

\section{Sample and Procedure}

We randomly selected a sample of every "nth" high school in California from the 2000-1 listing of the state's high schools (Education, 2001). A total of 491 questionnaires were mailed directly to high school principals, asking the principal to rate their department heads/lead teachers on three behavioral measures: follower performance, citizenship behaviors, and complaining behaviors. We received a total of 223 questionnaires from principals, a response rate of 45.4 per cent. For each responding principal, a separate confidential letter was sent to the department heads of the same school. ${ }^{1}$ This was done to assure independence of data between principal and teachers. A total of 1,060 confidential questionnaires were mailed to department heads/lead teachers. We received 342 completed teacher surveys, a response rate of 32.3 per cent. The teacher questionnaire focused on perceptions of the aversive leadership style of the principal, as well as teacher self-reports of job satisfaction, self-efficacy, and resistance behaviors.

\footnotetext{
1. Principal questionnaires were mailed directly to the high school, and completed questionnaires were returned using a prepaid returned envelope addressed to the researchers with a unique school identifier. Once principals' completed questionnaires were received, the schools were contacted directly to identify the names of the teacher department heads. Teacher questionnaires were then sent out with the teacher's unique name, department, school, and school address, and completed questionnaires were mailed back in a prepaid addressed returned envelope with a unique school and department identifier. Teacher surveys were subsequently matched up to the corresponding principal surveys.
} 
Overall, principals in the sample were rated by between one to five department head/lead teachers, and 95 out of 179 schools in our sample had more than one teacher rating each principal. On average, principals were rated by 1.91 teachers per school. To ensure that the dyadic, rather than group, level of analysis was appropriate for our sample as hypothesized, we conducted an analysis of interrater agreement following the procedures of Lindell, Brandt, and Whitney (1999) and obtained a mean $r^{*}{ }_{W G(J)}$ score of .60. Prior research suggests that a value of .70 or above is necessary to demonstrate consistency in order to aggregate scores to the group level (see George, 1990; Zohar, 2000). Thus, the dyadic level of analysis is appropriate for our sample. As a result, consistent with the work of Tepper et al. (2001a) and Barry and Watson (1996), the unit of analysis in this study is the leaderfollower dyad $(n=342)$.

In the respective cover letters, all principals and teachers were informed that they would not be individually identified, nor would individual schools be publicly revealed. To protect and assure confidentiality, all participants were given business reply envelopes to directly return their completed questionnaires to the research team. Principals' questionnaires were accompanied by a cover letter asking them to assess the performance of their department heads/lead teachers. The cover letter stated that their participation in the study would help to advance our understanding of what makes schools effective. The instructions were as follows: "In this section, we ask you to assess the department heads/lead teachers for English, History, Math, Science, and Physical Education. Using the scale listed below, please indicate your assessment of each teacher on each of the statements." Teachers were presented a similar cover letter, and the instructions varied only slightly in that the questionnaire asked teachers to rate the leadership behavior displayed by their principals. In a later section, teachers were asked to use the rating scale "to describe how accurately each statement describes how you feel" in response to items concerning their own job satisfaction, self-efficacy, and resistance behaviors. In addition, following Podsakoff, MacKenzie, Lee, and Podsakoff's (2003) suggestions for minimizing common method bias, we included explicit statements focused on protecting respondent anonymity and reducing evaluation apprehension, and defined ambiguous terms in order to improve scale items. All items were measured using a 5-point Likert scale ( $1=$ Strongly Disagree, 5 = Strongly Agree) unless otherwise indicated.

\section{Measures: Follower-Rated Items}

Aversive Leadership. Aversive leadership, as rated by teachers, consisted of six items used in previous research (see Pearce \& Sims, 2002) to assess intimidation and reprimanding behaviors. Teachers received the following written in- 
structions: "In this section please respond to each question as it applies to the leadership behavior displayed by your principal. Please circle the number that most accurately reflects your response, using the scale listed below." Sample items include: "The principal tries to influence me through threat and intimidation"; "I feel intimidated by his/her behavior"; "The principal lets me know about it when I perform poorly"; and "The principal points it out to me when my work is not up to par."

Follower Job Satisfaction. Hackman and Oldham's (1975) measure of overall job satisfaction was chosen over measures that tap more specific satisfactions such as pay, immediate supervisor, or working conditions (Cook, Hepworth, Wall, \& Warr, 1981). Items in this three-item scale include: "I am interested in my work"; "I feel energized by the work I do"; and "Generally speaking, I am very satisfied with my job."

Follower Self-Efficacy. Ten items were utilized to assess teacher self-efficacy in the classroom. These items were designed to tap into teachers' efficacy for classroom management, student engagement, and quality of instruction. The instructions stated: "These questions are designed to help us gain a better understanding of the things that may create difficulties for you in the classroom. Please indicate your opinion about each of the statements below." Sample items include: "How much can you do to control disruptive behavior in the classroom?" (classroom management); "How much can you motivate students who show low interest in schoolwork?" (student engagement); and "To what extent can you craft good questions for your students?" (quality of instruction). The response format was a 5-point Likert scale $(1=\mathrm{Not}$ at all, $5=\mathrm{A}$ Great Deal).

Follower Resistance. The 11-item scale related to resistance was based on a previously published questionnaire by Tepper et al. (2001a). Followers were asked to recall how often they had "resisted" requests from their leaders using a variety of tactics. Specifically, the instructions stated: "Teachers are frequently asked to do things at work. Sometimes these requests come from the Principal and at other times these requests come from fellow teachers. Sometimes teachers do not mind fulfilling the requests, while at other times they do not want to comply with the request. Listed below are different ways that teachers might resist the requests of others. Think about how often you engage in each tactic when you resist requests from your Principal." Sample items include, "I ignore the principal"; "I disregard what the principal says"; "I just say "no'"; and "I act like I was never asked to do it." The response format was a 5-point Likert scale ( $1=$ Never, 5 = Very Often). This technique of self-report questioning has been used in prior studies to indicate use of resistance tactics (see Tepper et al., 2001a). 


\section{Measures: Leader-Rated Items}

Follower Complaining Behaviors. Principals rated perceptions of their followers' complaining behaviors on a three-item scale. Items included: "Consumes a lot of time complaining about trivial matters"; "Tends to make "mountains out of molehills"”; "Always focuses on what's wrong with his/her situation rather than the positive side of it."

Follower Organizational Citizenship Behaviors (OCBs). Principals were asked to rate followers' OCBs on a shortened 12-item scale based on Organ (1988, 1997). These questions were designed to measure five aspects of OCBs: Altruism (e.g. "Helps orient new teachers even though it is not required"); Conscientiousness (e.g. "Conscientiously follows school regulations and procedures"); Sportsmanship (e.g. "Is mindful of how his/her behavior affects other teachers"); Courtesy (e.g. "Tries to avoid creating problems for other teachers"); and Civic Virtue (e.g. "Attends functions that are not required, but that help the school image").

Follower Performance. Principals rated perceptions of their followers' overall performance on a three-item scale. Items included: "Is one of my best teachers"; "All things considered, this teacher is outstanding"; and "All things considered, this teacher performs his/her job the way I like to see it performed."

\section{Results}

Descriptive statistics, intercorrelations, and reliabilities for each variable are listed in Table 1. As expected, there was a negative correlation between aversive leadership and follower job satisfaction $(r=-.31, p<.001)$ and self-efficacy $(r=$ $-.10, p<.10)$. Perceptions of aversive leadership were also positively correlated with followers' self-ratings of behavioral resistance $(r=.34, p<.001)$. In addition, follower ratings of the principals' aversive leadership behaviors were positively correlated with the leaders' independent ratings of teacher complaining behaviors $(r=.25, p<.001)$, and negatively correlated with citizenship behaviors $(r=-.30, p<.001)$. Finally, performance of the teacher was also negatively correlated with perceptions of the principal's aversive leadership behaviors $(r=$ $-.28, p<.001)$.

We utilized hierarchical regression analyses to examine the seven hypotheses. In the first step, we entered leader tenure and organizational size as controls. Neither control variable was significantly related to perceptions of aversive leadership. In the second step, we entered all of the leader- and follower-rated measures. Consistent with expectations, follower job satisfaction ( $b$ $=-.18, p<.01)$ and resistance $(b=.22, p<.001)$ were significantly related to 


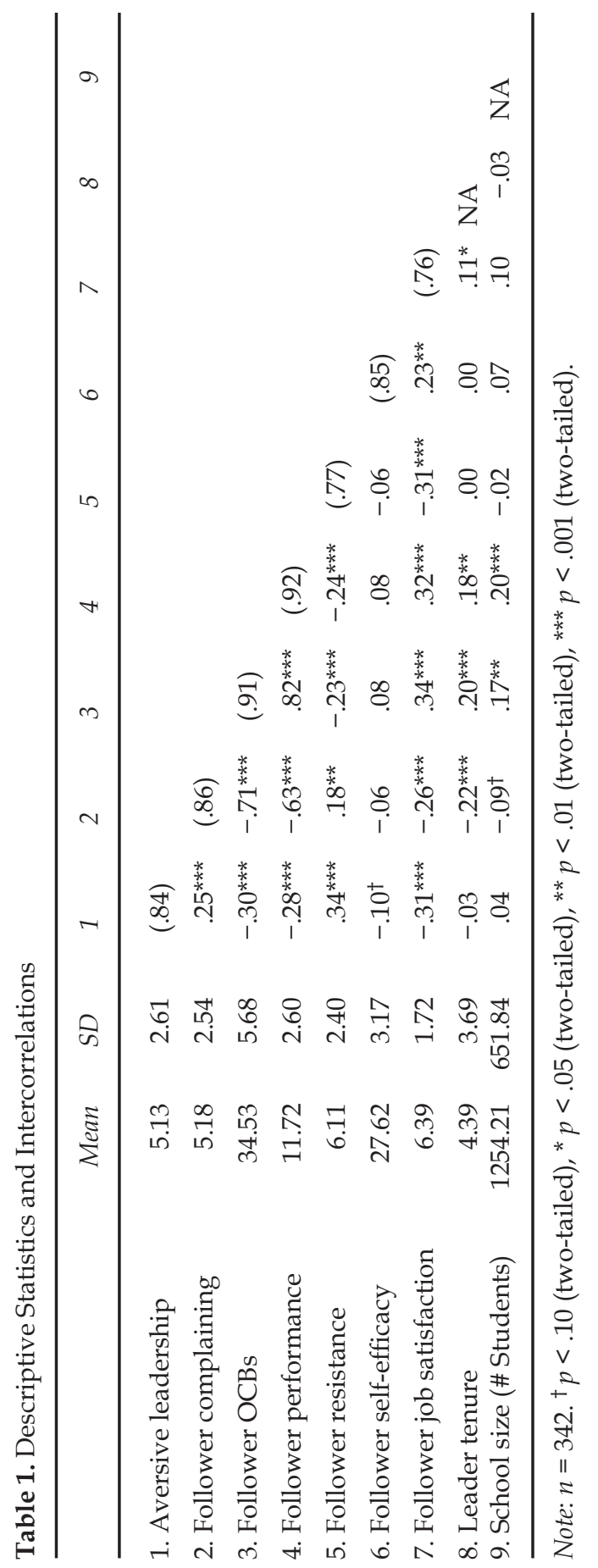


perceptions of aversive leadership, providing support for Hypotheses 1 and 3. Follower self-efficacy, however, was unrelated to perceptions of aversive leadership $(b=-.01, n s)$, suggesting that followers who perceived their leaders to be aversive were no less likely to feel that they could impact their classrooms positively in terms of classroom management, student engagement, and quality of instruction. Thus, Hypothesis 2 was unsupported. Interestingly, the three leader-rated outcome variables (OCBs, complaining, and performance) were also not significantly related to perceptions of aversive leadership, providing no support for Hypotheses 4, 5, and 6.

In the remaining regressions, we followed the procedure outlined by Farh, Podsakoff, and Organ (1990) (see also Pearce \& Sims, 2002) for usefulness analysis with hierarchical multiple regression. As an important aspect of this research was to examine the relative usefulness of follower- versus leader-rated outcomes in explaining perceptions of aversive leadership, we alternated the order of entry for leader-rated versus follower-rated outcome variables. In the second set of analyses (see the middle section of Table 2), we added the three leader-rated outcome variables in step two (complaining, performance, and OCBs), followed by the follower-rated outcome variables in step three (job satisfaction, resistance, and self-efficacy). Aversive leadership was the criterion variable. In the final set of analyses (see the right section of Table 2), we added the three followerrated outcome variables in step two (job satisfaction, resistance, and self-efficacy), followed by the leader-rated outcome variables in step three (complaining, performance, and OCBs). The appropriate test statistics for the usefulness analysis are the $\Delta R_{2}$ statistics found at the bottom of the table (in bold and underlined). The $\Delta R_{2}$ for the addition of the follower-rated variables in step 3 (after all leader-rated variables were entered first) was .10 $(p<.001)$, while the $\Delta R_{2}$ for the leader-rated variables in step 3 (after all follower-rated variables were entered first) was .02 (ns).

Thus, the follower-rated variables explained a significantly greater amount of the variance in perceptions of aversive leadership, even after taking into account all of the leader-rated variables. The reverse was not the case: the leaderrated variables were non-significant when the follower-rated variables were entered first, and together did not explain significantly more of the variance in perceptions of aversive leadership, thus providing support for Hypothesis 7. These results provide some evidence for the assertion that a negative Romance of Leadership effect may be partially responsible for our findings. Although leaders' ratings of followers' OCBs, complaining, and performance were each unrelated to perceptions of aversive leadership in step three of all analyses, followers who reported that their own job satisfaction was low and their resistance behaviors were high were more likely to also rate their leader as more aversive, suggesting they may be (mis)attributing the source of these outcomes to their leader. Alternatively, it is important to note that we cannot definitively 


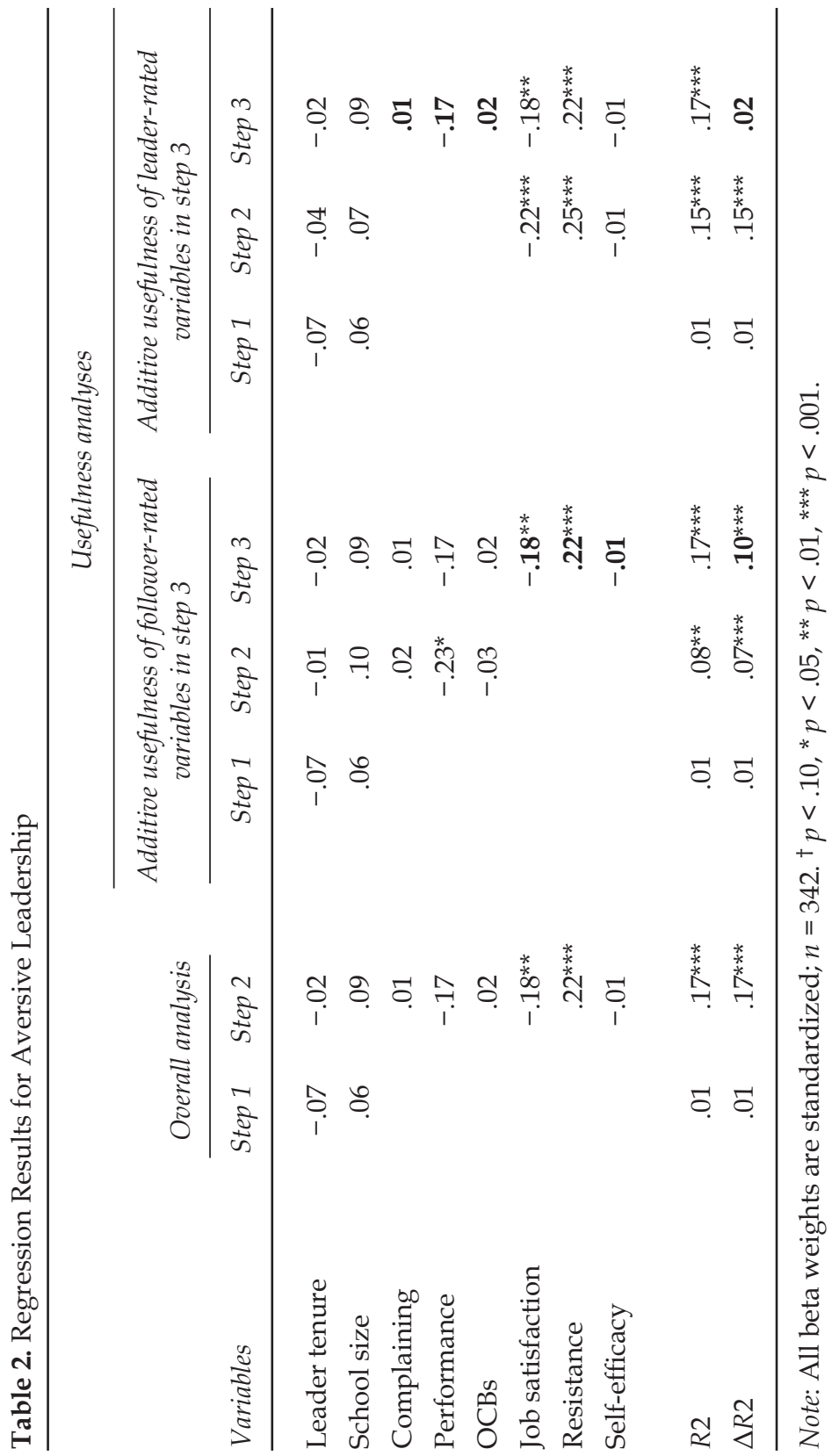




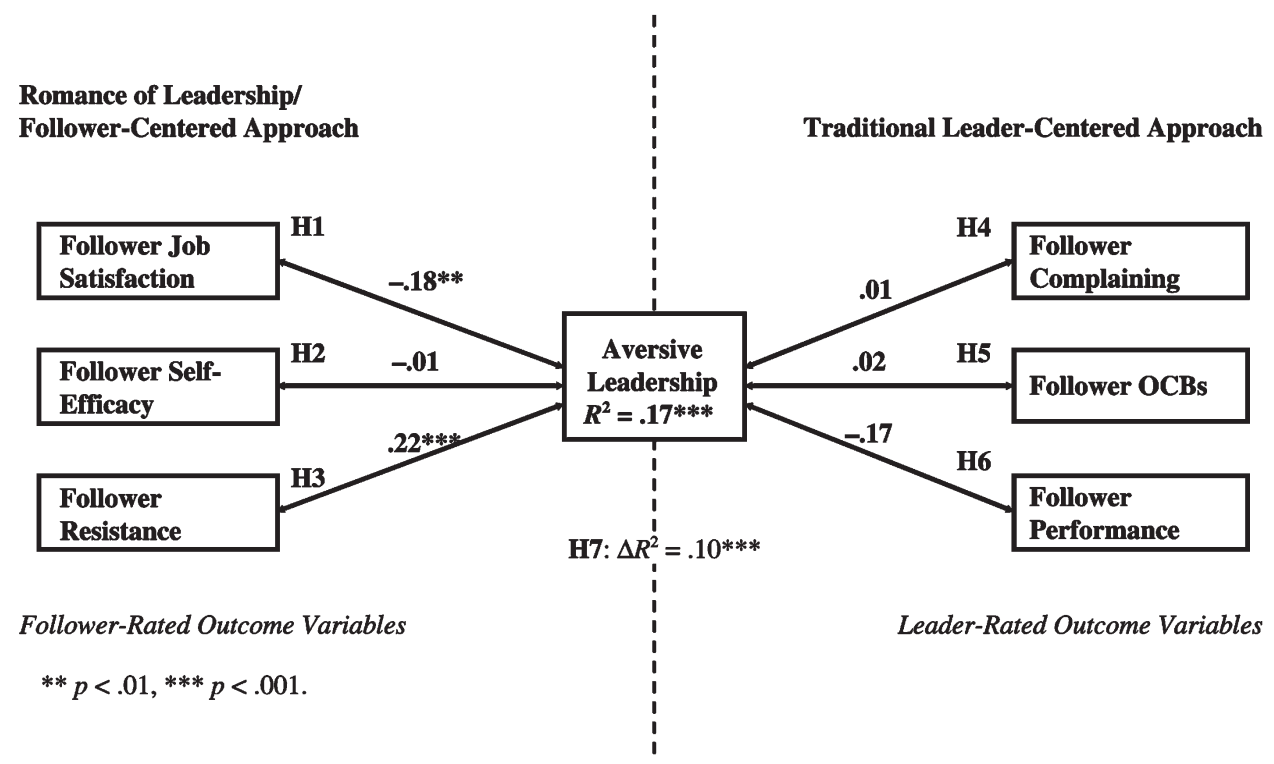

Figure 2. Results for the hypothesized relationships: a comparison of approaches.

rule out the possibility that the ratings legitimately reflect the influence of aversive leadership. The model of the dyadic relationships supported based upon the regression results is provided in Figure 2.

\section{Discussion}

Consistent with previous research on aversive forms of leadership, our analyses support earlier findings that components of aversive leadership are negatively related to several traditional follower outcomes. However, our findings suggest that perceptions of aversive leadership are only significantly related to follower-rated outcomes of job satisfaction and resistance, suggesting that this relationship may be largely due to a negative Romance of Leadership or "horns" effect. Principals did not perceive that these same teachers who independently rated them as aversive were significantly lower performers, exhibited more complaining, or fewer citizenship behaviors, indicating that the negative aspects of the aversive leadership reported by teachers may have been more perceived than real. As follower-rated outcomes were more strongly associated with perceptions of aversive leadership than leader-rated outcomes, then those outcomes may be more likely due to an attributed "horns" effect: i.e. "I don't like my job and often ignore my principal because he/she is a bad leader" is a more convenient attribution process than taking into account all of the individ- 
ual, dyadic, professional, and organizational factors that influence job satisfaction and resistance behaviors.

Supporting this interpretation, it is important to note that we might have drawn a different conclusion had we not also included the follower-rated variables in the model. Interpretations based solely on the leader-rated predictor variables would suggest that aversive leadership may in fact be related to significantly lower follower performance $(b=-.23, p<.05)$. However, when we also examine the relationships of perceptions of aversive leadership to followers' self-rated outcomes, this relationship becomes non-significant. Thus, our findings provide some evidence for the fact that followers' perceptual ratings of their own outcomes may be more predictive of leadership ratings than other, perhaps more objective, ${ }^{2}$ ratings of follower performance and other behavioral outcomes. This suggests that followers may have a somewhat negative romanticized notion of leadership, whereby perceptions of aversive leadership are constructed from their own perceived negative experiences rather than from more objective measures of their own behaviors.

We argue that the usefulness analysis is telling in that follower-rated outcome variables are more predictive of leadership ratings than are leader-rated follower outcomes. We further suggest that it is plausible that these results indicate that when followers look at their own negative outcomes, they are misattributing them to their leaders, suggesting a negative form of the Romance of Leadership (i.e. follower evaluations of outcome variables are being used to (mis)construct attributions of leadership), or horns effect. We do recognize that not directly assessing the Romance of Leadership is an important limitation of the current study. Nevertheless, for the most part previous research has simply assumed that these follower-rated negative outcomes are an "objective" reflection of aversive leadership. Our results, however, reflect the potentially powerful nature of the Romance of Leadership perspective, and suggest that future research should utilize the Romance of Leadership Scale (RLS) directly, rather than assuming that negative outcomes are direct and implicitly causal outcomes of the dark side of leadership. Future research would benefit from a closer integration of the Romance of Leadership and the dark side of leadership perspectives in order to examine the possibility that negative follower outcomes are being misattributed to leadership. Following Fairhurst (2007, p. 4), we hope that this integration will help to emphasize that "leadership need not have existed, or need not be at all as it is . . leadership, or leadership as it is at present, is not determined by the nature of things; it is not inevitable".

\footnotetext{
${ }^{2}$ While it is reasonable to assume that both self-report and other reports contain some bias, previous research suggests that the most accurate or least biased perspective likely depends on which variable is being assessed (Donaldson \& Grant-Vallone, 2002). According to these researchers, measures of performance and mental health are most likely to be misleading, suggesting that leader's ratings of followers' performance, $\mathrm{OCBs}$, and complaining behaviors may be closer to true ratings of these variables.
} 
Although it might also be argued that our findings may be due to singlesource bias, or the fact that the follower-rated outcome ratings were obtained from the same source as the perceptions of aversive leadership, if this were the case then the results for follower self-efficacy ratings would also be expected to explain a significant amount of the variance in aversive leadership ratings. In fact, follower self-efficacy was entirely unrelated to perceptions of aversive leadership $(b=-.01, n s)$, despite the fact that these ratings were obtained from the same source as well. We suggest that these findings may be due to the fact that teachers have a great deal of perceived control over their performance in the actual classroom, and the measure of self-efficacy utilized was specifically developed to tap into this control. Therefore, it is perhaps not surprising that teachers' reported self-efficacy was unrelated to perceptions of aversive leadership in our sample: teachers are likely able to maintain their independence and self-efficacy in the classroom in spite of their principals' perceived or actual aversive behaviors (see also Hoy \& Woolfolk, 1993). Thus, while followers' more global, overall job satisfaction and resistance behaviors were perceived as related to perceptions of aversive leadership, their ability to perform effectively in the classroom was not, suggesting that the significant findings obtained for job satisfaction and resistance are unlikely to be due simply to single-source bias. However, we also recognize that although follower reports of self-efficacy do not correlate with other follower reports, this does not definitively rule out the problem of common method variance. The follower's feelings of self-efficacy could also be independent in that selfefficacy measures the follower's view of self and not, as the other measures, his or her view of the leader.

\section{Implications, Limitations, and Directions for Future Research}

Our results do not undermine the practical implication that effective leaders should continue to avoid intimidation and reprimanding behaviors. Principals should work with teachers to define non-intimidating methods and leadership behaviors, such as participative and shared leadership (see Pearce \& Conger, 2003). While our results draw attention to the fact that followers' constructions of their own dissatisfaction and resistance may also play an important role in perceptions of aversive leadership, they do not undermine the fact that coercive or intimidating leadership styles have viable alternatives that may more positively contribute to improved follower outcomes. However, our results are consistent with a Romance of Leadership approach, which "emphasizes followers and their contexts for defining leadership itself and for understanding its significance" (Meindl, 1995, p. 330). 
An important limitation of the study is its use of a common method, questionnaires with fixed response formats. To minimize this limitation, we utilized two separate and confidential questionnaires, as well as open-ended comments to supplement our findings. In addition, utilization of the method for minimizing common source bias (Podsakoff et al., 2003) and examining potential effects of self-report bias (a factor analysis of the self-reported data collected) did not reveal any systematic bias concerns (see Podsakoff \& Organ, 1986).

Another potential limitation of this study is that the halo/horns bias is often treated as measurement error. For example, these biases may be due to a leader having a positive/negative relationship with the follower, and a halo/ horns bias may occur if one characteristic of the leader, more than others, has an effect on followers' ratings (or vice versa). To partially ensure that this was a systematic horns bias, rather than a simple effect of the respondent rating the target similarly on all measures regardless of content, the rating questions were interspersed with the other questions, forcing the respondents to read and answer the questions independently, and reverse-scored items were utilized as well.

Generalizability of the results poses another potential issue, and extending our illustrative example to other settings is clearly necessary. However, it is also possible that the context of this study may relate well to dyadic relationships in larger management and leadership settings, such as dynamic public service and knowledge industry settings where the intellectual capital and voluntary contributions of professionals are equally important. Further, aversive leadership is clearly not unique to the educational context, as evidenced in the literature review above. Due to the cross-sectional design, questions regarding the effects of persistent long-term perceptions of aversive leadership were also not addressed in the current study. Future research might examine, for example, specific actions that principals and teachers can take in order to change negative perceptions and improve dyadic relations. Both leaders and followers might benefit from training and development to explore the underlying sources of job satisfaction and resistance, and explore at the dyadic level how perceptions of control and causality may differ between leaders and followers.

In addition, our results supplement Perie et al.'s (1997) findings that involving teachers in school-wide policy decisions and giving them greater control in their classrooms are associated with higher levels of job satisfaction. Our findings suggest that greater involvement and empowerment of teachers may also positively impact principal-teacher relations, as teachers who are more satisfied are likely to attribute these positive contextual changes to the principal's leadership. Thus, principals should note that addressing more of the contextual causes of low job satisfaction and resistance will likely lead to better leadership ratings. In contrast, unsatisfied teachers are likely to perceive the principal in a negative light, be less committed to the organization, 
and may ultimately leave the school. All of these potential effects can negatively impact student learning, despite the fact that the leader judges the teacher's performance to be "good". Thus, follower-rated outcomes may very well affect the organization's bottom line equally or to a greater extent than more "objective" performance ratings.

In addition, our results suggest that parents, district leaders, and policy writers may often attribute teacher performance to good leadership from the school's principal, when he or she may have little real direct impact on teacher performance. In addition, principals may proactively engage in self-deception and impression management techniques to further these attributions (see Gray \& Densten, this volume), romanticizing followers into believing that good performance should be attributable to good school leadership. For these reasons, performance evaluations of principals should include multiple raters as well as taking into account followers' job satisfaction and resistance behaviors, as teachers' ratings of their leaders are likely to be importantly influenced by these variables. Finally, our results may have implications for selection as well. Teachers high in negative affectivity may be less likely to be satisfied and more likely to resist principal initiatives, which could lead to a negative cycle in which principals are unable to enact changes, use progressively more forceful and directive leadership styles, and are subsequently rated as aversive leaders.

Future researchers thus have a number of opportunities to expand upon these results. For example, researchers might utilize Meindl and Ehrlich's (1987) RLS to attempt to understand potential dispositional differences among followers who are more or less likely to attribute outcomes to leaders. While this research has been examined in other settings (e.g. Bligh et al., 2005), we are unaware of any studies that have examined the RLS in relation to negative or destructive perceived outcomes of leadership at the dyadic level. In addition, it is important to note that individual differences might influence these results as well. For example, negative affect or chronic job dissatisfaction may also predict follower complaining, resistance, and OCBs, independent of the leader and the leader-follower relationship. Future research should take into account these potential individual differences to avoid over-attributing follower outcomes to leaders and leadership.

\section{Conclusion}

Following Jackson (2005, p. 1324), we suggest "perhaps, at the end of the day, a healthy blend of romantic affliction and suspicious skepticism is what is required in our deliberations regarding leadership . . . leadership can provide a powerful source of inspiration to take action but it can also blind us in our desire to believe in leaders as well as our deeply felt need to be well led". Our results suggest that our attributions about the potential detrimental perceived 
effects of being poorly led may be important to keep in mind as well. The "Romance of Leadership is about the thoughts of followers: how leaders are constructed and represented in their thought systems" (Meindl, 1995, p. 330). We hope this initial study will encourage others to further explore the implications when followers construct and represent their leader in aversive, and even destructive terms, and blame him or her for detrimental outcomes that may or may not be within the leader's control.

\section{References}

Andersson, L.M., \& Pearson, C.M. (1999). Tit for tat? The spiraling effect of incivility in the workplace. Academy of Management Review, 24, 452-471.

Awamleh, R., \& Gardner, W.L. (1999). Perceptions of leader charisma and effectiveness: The effects of vision content, delivery, and organizational performance. Leadership Quarterly, 10, 345-373.

Ashforth, B.E. (1994). Petty tyranny in organizations. Human Relations, 47, 755-778.

Ashforth, B.E. (1997). Petty tyranny in organizations: A preliminary examination of antecedents and consequences. Canadian Journal of Administrative Sciences, 14, 126-140.

Ball, G.A., Sims, H.P., \& Trevino, L.K. (1994). Just and unjust punishment: Influences on subordinate performance and citizenship. Academy of Management Journal, 37, 299-322.

Bandura, A. (1997). Self-efficacy: The exercise of control. New York: W.H. Freeman.

Bandura, A. (1986). Social foundations of thought and action: A social cognitive theory. Englewood Cliffs, NJ: Prentice Hall.

Baron, R.A. (1986). Behavior in organizations: Understanding and managing the human side of work (2nd edn.). Boston, MA: Allyn \& Bacon.

Baron, R.A. (1988). Negative effects of destructive criticism: Impact on conflict, self-confidence, and task performance. Journal of Applied Psychology, 73, 199-207.

Baron, R.A. (2004). Workplace aggression and violence: Insights from basic research. In R.W. Griffin \& A.M. O'Leary-Kelly (Eds.), The dark side of organizational behavior (pp. 698-708). San Francisco, CA: Jossey-Bass.

Baron, R.A., \& Neuman, J.H. (1996). Workplace violence and workplace aggression: Evidence on their relative frequency and potential causes. Aggressive Behavior, 22, 161-173.

Barry, B., \& Watson, M.R. (1996). Communication aspects of dyadic social influence in organizations: A review and integration of conceptual and empirical developments. In B.R. Burleson \& A.W. Kunkel (Eds.), Communication yearbook, Vol. 19 (pp. 269-317). Thousand Oaks, CA: Sage.

Bass, B.M. (1990). Bass and Stogdill's handbook of leadership: Theory, research and managerial expectations (3rd edn.). New York: Free Press.

Bass, B.M., \& Steidlmeier, P. (1999). Ethics, character, and authentic transformational leadership. The Leadership Quarterly, 10, 181-217.

Berger, P.L., \& Luckmann, T. (1966). The social construction of reality. Garden City, NY: Doubleday. 
Bies, R.J., Tripp, T.M., \& Kramer, R.M. (1997). At the breaking point: Cognitive and social dynamics of revenge in organizations. In R.A. Giacalone \& J. Greenberg (Eds.), Antisocial behavior in organizations (pp. 18-36). Thousand Oaks, CA: Sage.

Bjorkqvist, K., Osterman, K., \& Hjelt-Back, M. (1994). Aggression among university employees. Aggressive Behavior, 20, 173-184.

Bligh, M.C., Kohles, J.C., \& Pillai, R. (2005). Crisis and charisma in the California recall election. Leadership, 1(3), 323-352.

Bligh, M.C., \& Meindl, J.R. (2004). The cultural ecology of leadership: An analysis of popular leadership books. In D.M. Messick \& R.M. Kramer (Eds.), The psychology of leadership: New perspectives and research (pp. 11-52). Hillsdale, NJ: Erlbaum.

Boorstin, D.J. (1961). The image. New York: Atheneum.

Bowman, J.S. (1999). Performance appraisal: Verisimilitude trumps veracity. Public Personnel Management, 28(4), 557-577.

Burns, J.M. (2005). Leadership. Leadership, 1, 11-12.

Calder, B.J. (1977). An attribution theory of leadership. In B.M. Staw \& G.R. Salancik (Eds.), New directions in organizational behavior (pp. 179-204). Chicago, IL: St Clair.

Chen, C., \& Meindl, J.R. (1991). The construction of leadership images in the popular press: The case of Donald Burr and People Express. Administrative Science Quarterly, 36(4), 521-552.

Conger, J.A. (1989). The charismatic leader: Behind the mystique of exceptional leadership. San Francisco, CA: Jossey-Bass.

Conger, J.A. (1990). The dark side of leadership. Organizational Dynamics, 19(2), 44-55.

Conger, J.A., \& Kanungo, R.N. (1998). Charismatic leadership in organizations. Thousand Oaks, CA: Sage.

Cook, J.D., Hepworth, S.J., Wall, T.D., \& Warr, P.B. (1981). Experience of work: A compendium and review of 249 measures and their use. New York: Academic Press.

Donaldson, S.I., \& Grant-Vallone, E. (2002). Understanding self-report bias in organizational behavior research. Journal of Business and Psychology, 17(2), 245- 260.

Dubois, P. (1979). Sabotage in industry. Harmondsworth, Middlesex: Pelican.

Duncan, S., Estabrooks, C.A., \& Reimer, M. (2000, March/April). High rates of workplace violence against nurses: Findings of the Alberta Nurse Survey. Alberta RN, 271-279.

Education, California Department of. (2001). California public school directory 2001. Sacramento, CA: CDE Press.

Ehrlich, H.J., \& Larcom, B.E.K. (1994). Ethnoviolence in the workplace. Baltimore, MD: Center for the Applied Study of Ethnoviolence.

Eisenberg, N., \& Miller, P.A. (1987). The relations of empathy to prosocial and related behaviors. Psychological Bulletin, 101(1), 91-119.

Fairhurst, G.T. (2007). Discursive leadership: In conversation with leadership psychology. Los Angeles, CA: Sage.

Farh, J., Podsakoff, P.M., \& Organ, D.W. (1990). Accounting for organizational citizenship behavior: Leader fairness and task scope versus satisfaction. Journal of Management, 16, 705-721.

Gardner, W.L. (2003). Perceptions of leader charisma, effectiveness, and integrity. Management Communication Quarterly, 16(4), 502-527. 
George, J.M. (1990). Personality, affect, and behavior in groups. Journal of Applied Psychology, 75(2), 107-116.

Gergen, K.J. (1999). An invitation to social construction. London; Thousand Oaks, CA: Sage.

Giacalone, R.A., \& Rosenfeld, P. (1987). Reasons for employee sabotage in the workplace. Journal of Business Psychology, 1, 367-378.

Glomb, T.M., \& Liao, H. (2003). Interpersonal aggression in work groups: Social influence, reciprocal, and individual effects. Academy of Management Journal, 46(4), 486-497.

Goldman, A. (2006). Personality disorders in leaders: Implications of the DSM IV-TR in assessing dysfunctional organizations. Journal of Managerial Psychology, 21(5), 392-414.

Goode, W.J. (1978). The celebration of heroes. Berkeley, CA: University of California Press.

Graydon, J., Kasta, W., \& Khan, P. (1994). Verbal and physical abuse of nurses. Canadian Journal of Nursing Administration, November-December, 70-89.

Griffin, R.W., \& O'Leary-Kelly, A.M. (Eds.) (2004). The dark side of organizational behavior. San Francisco, CA: Jossey-Bass.

Grint, K. (2000). The arts of leadership. Oxford: Oxford University Press.

Hackman, J.R., \& Oldham, G.R. (1975). Development of the Job Diagnostic Survey. Journal of Applied Psychology, 60, 159-170.

Harlos, K., \& Pinder, C. (1999). Patterns of organizational injustice: A taxonomy of what employees regard as unjust. In Advances in qualitative organizational research, Vol. 2 (pp. 97-125). Greenwich, CT: JAI Press.

Hogan, R., \& Hogan, J. (2001). Assessing leadership: A view from the dark side. International Journal of Selection and Assessment, 9, 40-51.

Hogan, R., Raskin, R., \& Fazzini, D. (1990). The dark side of charisma. In K.E. Clark \& M.B. Clark (Eds.), Measures of leadership (pp. 343-354). West Orange, NJ: Leadership Library of America.

Hollinger, R.D., \& Clark, J.P. (1983). Theft by employees. Lexington, MA: Lexington Books.

House, R.J., \& Howell, J.M. (1992). Personality and charismatic leadership. The Leadership Quarterly, 3(2), 81-108.

Howell, J.M. (1988). Two faces of charisma: Socialized and personalized leadership in organizations. In J.A. Conger \& R.A. Kanungo (Eds.), Charismatic leadership: The elusive factor in organizational effectiveness (pp. 213-246). San Francisco, CA: Jossey-Bass.

Hoy, W.K., \& Woolfolk, A.E. (1993). Teachers' sense of efficacy and the organizational health of schools. Elementary School Journal, 93, 356-372.

Hunter, J.E., Gerbing, D.W., \& Boster, F.J. (1982). Machiavellian beliefs and personality: Construct invalidity of the Machiavellianism dimension. Journal of Personality and Social Psychology, 43(6), 1293-1305.

Jackson, B. (2005). The enduring romance of leadership studies. Journal of Management Studies, 42(6), 1311-1324.

Jansen, K.J., \& Kristof-Brown, A. (2006). Toward a multidimensional theory of person-environment fit. Journal of Managerial Issues, 18(2), 193-214.

Keashly, L., \& Jagatic, K. (2003). By any other name: American perspectives on workplace bullying. In S. Einarsen, H. Hoel, D. Zapf, \& C. Cooper (Eds.), Bullying and emotional abuse in the workplace: International research and practice perspectives (pp. 31-61). London: Taylor \& Francis.

Kellerman, B. (2004). Bad leadership: What it is, how it happens, why it matters. Boston, MA: Harvard Business School Press. 
Kets de Vries, M.F.R., \& Miller, D. (1985). Narcissism and leadership: An object relations perspective. Human Relations, 38, 583-601.

Klapp, O.E. (1964). Symbolic leaders. Chicago, IL: Aldine.

Lance, C.E., LaPointe, J.A., \& Fisicaro, S.A. (1994). Tests of three causal models of halo rater error. Organizational Behavior and Human Decision Processes, 13, 253-277.

Lindell, M.K., Brandt, C.J., \& Whitney, D.J. (1999). A revised index of interrater agreement for multi-item ratings of a single target. Applied Psychological Measurement, 23, 127-135.

Lipman-Blumen, J. (2006). The allure of toxic leaders: Why we follow destructive bosses and corrupt politicians - and how we can survive them. Oxford: Oxford University Press.

Locke, E.A. (1991). The motivation sequence, the motivation hub, and the motivation core. Organizational Behavior and Human Decision Processes, 50, 288-299.

Locke, E.A. (2000). The prime movers: Traits of the great wealth creators. New York: AMACOM.

McClelland, D.C. (1975). Power: The inner experience. New York: Irvington.

Maddux, J.E. (1995). Self-efficacy theory: An introduction. In J.E. Maddux (Ed.), Self-efficacy, adaptation, and adjustment: Theory, research, and application (pp. 3-33). New York: Plenum Press.

Mantell, M. (1994). Ticking bombs: Defusing violence in the workplace. Burr Ridge, IL: Irwin.

Meindl, J.R. (1990). On leadership: An alternative to the conventional wisdom. In B.M. Staw \& L.L. Cummings (Eds.), Research in organizational behavior, 12, 159-203. Greenwich, CT: JAI Press.

Meindl, J.R. (1995). The romance of leadership as a follower-centric theory: A social constructionist approach. The Leadership Quarterly, 6(3), 329-341.

Meindl, J.R., \& Ehrlich, S.B. (1987). The romance of leadership and the evaluation of organizational performance. Academy of Management Journal, 30, 91-109.

Meindl, J.R., Ehrlich, S.B., \& Dukerich, J.M. (1985). The romance of leadership. Administrative Science Quarterly, 30, 78-102.

Mumford, M.D., Gessner, T.L., Connelly, M.S., O'Connor, J.A., \& Clifton, T.C. (1993). Leadership and destructive acts: Individual and situational influences. The Leadership Quarterly, 4(2), 115-147.

Neuman, J.H., \& Baron, R.A. (1997). Aggression in the workplace. In R.A. Giacalone \& J. Greenberg (Eds.), Antisocial behavior in organizations (pp. 37-67). Thousand Oaks, CA: Sage.

Neuman, J.H., \& Baron, R.A. (1998). Workplace violence and workplace aggression: Evidence concerning specific forms, potential causes, and preferred targets. Journal of Management, 24, 391-419.

Nisbett, R.D., \& Wilson, T.D. (1977). The halo effect: Evidence for unconscious alteration of judgments. Journal of Personality and Social Psychology, 35, 250-256.

O'Connor, J., Mumford, M.D., Clifton, T.C., Gessner, T.L., \& Connelly, M.S. (1995). Charismatic leaders and destructiveness: An historiometric study. The Leadership Quarterly, 6(4), 529-555.

Organ, D.W. (1988). Organizational citizenship behavior: The good soldier syndrome. Lexington, MA: Lexington Books.

Organ, D.W. (1997). Organizational citizenship behavior: It's construct clean-up time. Human Performance, 10, 85-97. 
Pearce, C.L., \& Conger, J.A. (Eds.) (2003). Shared leadership: Reframing the hows and whys of leadership. Thousand Oaks, CA: Sage.

Pearce, C.L., \& Giacalone, R.A. (2003). Teams behaving badly: Factors associated with anticitizenship behavior in teams. Journal of Applied Social Psychology, 33, 58-75.

Pearce, C.L., \& Sims, H.P. (2002). Vertical versus shared leadership as predictors of the effectiveness of change management teams: An examination of aversive, directive, transactional, transformational and empowering leader behavior. Group Dynamics: Theory, Research, and Practice, 6(2), 172-197.

Pearce, C.L., Sims, H.P., Jr., Cox, J.F., Ball, G., Schnell, E., Smith, K.A., \&

Trevino, L. (2003). Transactors, transformers and beyond: A multi-method development of a theoretical typology of leadership. Journal of Management Development, 22(4), 273-307.

Pearson, C., Andersson, L., \& Porath, C. (2000). Assessing and attacking workplace incivility. Organizational Dynamics, Fall, 129-137.

Pearson, C.M., \& Porath, C.L. (2004). On incivility, its impact, and directions for future research. In R.W. Griffin \& A.M. O'Leary-Kelly (Eds.), The dark side of organizational behavior. San Francisco, CA: Jossey-Bass.

Perie, M., Baker, D.P., \& Whitener, S. (1997). Job satisfaction among America's teachers: Effects of workplace conditions, background characteristics, and teacher compensation. Washington, DC: US Department of Education.

Podsakoff, P., MacKenzie, S., Lee, J., \& Podsakoff, N. (2003). Common method biases in behavioral research: A critical review of the literature and recommended remedies. Journal of Applied Psychology, 88(5), 879-903.

Podsakoff, P., \& Organ, D.W. (1986). Self reports in organization research: Problems and prospects. Journal of Management, 12, 531-544.

Robinson, S.L., \& Bennett, R.J. (1995). A typology of deviant workplace behaviors: A multidimensional scaling study. Academy of Management Journal, 38, 555-572.

Salancik, G.R., \& Pfeffer, J. (1978). A social information processing approach to attitudes and task design. Administrative Science Quarterly, 23, 224-253.

Sandowsky, D. (1995). The charismatic leader as narcissist: Understanding the abuse of power. Organizational Dynamics, 24(4), 57-71.

Schwarzer, R. (2004). Managing stress at work through preventive and proactive coping. In E.A. Locke (Ed.), The Blackwell handbook of principles of organizational behavior (pp. 342-355). Oxford: Blackwell Publishing.

Shamir, B., Pillai, R., Bligh, M.C., \& Uhl-Bien, M. (Eds.) (2007). Follower-centered perspectives on leadership: A tribute to the memory of James R. Meindl. Charlotte, NC: Information Age Publishing.

Skarlicki, D.P., \& Folger, R. (1997). Retaliation in the workplace: The roles of distributive, procedural, and interactional justice. Journal of Applied Psychology, 82, 434-443.

Sofield, L., \& Salmond, S.W. (2003). Workplace violence: A focus on verbal abuse and intent to leave the organization. Orthopaedic Nursing, 22(4), 274-283.

Spector, G. (1987). Method variance as an artifact in self-reported affect and perceptions at work: Myth or significant problem? Journal of Applied Psychology, 72, 438-443.

Tepper, B. (2000). Consequences of abusive supervision. Academy of Management Journal, $43(2), 178-181$.

Tepper, B. (2001). Health consequences of organizational injustice: Tests of main and interactive effects. Organizational Behavior and Human Decision Processes, 86(2), 197-216. 
Tepper, B., Duffy, M., \& Shaw, J. (2001a). Personality moderators of the relationship between abusive supervision and subordinates' resistance. Journal of Applied Psychology, 86(5), 974-983.

Tepper, B., Hoobler, J., Duffy, M., \& Ensley, M. (2004). Moderators of the relationships between coworkers' organizational citizenship behavior and fellow employees' attitudes. Journal of Applied Psychology, 89(3), 455-466.

Tepper, B.J., Lockhart, D., \& Hoobler, J. (2001b). Justice, citizenship, and role definition effects. Journal of Applied Psychology, 86, 789-796.

Tepper, B.J., \& Taylor, E.C. (2003). Relationships among supervisors' and subordinates' procedural justice perceptions and organizational citizenship behaviors. Academy of Management Journal, 46(1), 97-105.

Thorndike, E.L. (1920). A constant error in psychological ratings. Journal of Applied Psychology, 4, 25-29.

Torestad, B. (1990). When is anger provoking? A psychophysical study of perceived causes of anger. Aggressive Behavior, 16, 9-26.

van Knippenberg, D., van Knippenberg, B., \& Giessner, S.F. (2007). Extending the followercentered perspective on leadership: A social identity analysis of followers' role in leadership effectiveness. In B. Shamir, R. Pillai, M.C. Bligh, \& M. Uhl-Bien (Eds.), Followercentered perspectives on leadership: A tribute to the memory of James R. Meindl (pp. 51-70). Charlotte, NC: Information Age Publishing.

Viswesvaran, C., Schmidt, F.L, \& Ones, D.S. (2005). Is there a general factor in ratings of job performance? A meta-analytic framework for disentangling substantive and error influences. Journal of Applied Psychology, 90(1), 108-131.

Weick, K. (2007). Romancing, following, and sensemaking: James Meindl's legacy. In B. Shamir, R. Pillai, M.C. Bligh, \& M. Uhl-Bien (Eds.), Follower-centered perspectives on leadership: A tribute to the memory of James R. Meindl (pp. 279-291). Charlotte, NC: Information Age Publishing.

Yukl, G.A. (1999). An evaluation of the conceptual weaknesses in transformational and charismatic leadership theories. The Leadership Quarterly, 10(2), 285-305.

Yukl, G.A. (2002). Leadership in organizations (5th edn.). Englewood Cliffs, NJ: Prentice Hall.

Zellars, K.L., Tepper, B.J., \& Duffy, M.K. (2002). Abusive supervision and subordinates' organizational citizenship behavior. Journal of Applied Psychology, 87(6), 1068-1077.

Zohar, D. (2000). A group-level model of safety climate: Testing the effect of group climate on microaccidents in manufacturing jobs. Journal of Applied Psychology, 85(4), 587-596. 